\title{
Physiologic Studies of Antidiuretic Hormone by Its Direct Measurement in Human Plasma *
}

\author{
J. W. Czaczkes, $†$ C. R. Kleeman, and M. Koenig with the technical \\ assistance of Ralph Boston \\ (From the Departments of Medicine, Cedars-Sinai Hospitals, Mount Sinai Hospital Division, \\ and the University of California Medical Center, Los Angeles, Calif.)
}

Research on mammalian antidiuretic hormone $(\mathrm{ADH})$ has been seriously limited by the lack of techniques for detection of physiological levels of $\mathrm{ADH}$ in blood and plasma.

The bioassay of Jeffers, Livezey, and Austin (1), using the ethanol-anesthetized rat for $\mathrm{ADH}$ in mammalian plasma, was significantly refined by Dicker (2), who was able to detect as little as 2 $\mu \mathrm{U} \mathrm{ADH}$ per $\mathrm{ml}$ of plasma. More recently, Heller and Stulc (3), using rats with exteriorized urinary bladders, could detect as little as $0.65 \mu \mathrm{U}$ per $\mathrm{ml}$ of plasma. With this technique Heller and Stulc (4) found mean levels of $1.67 \mu \mathrm{U}$ per $\mathrm{ml}$ of $\mathrm{ADH}$ in the plasma of "normally" hydrated men.

The present study was undertaken to evaluate Heller's procedure and, if possible, to utilize it to study the release, turnover, and action of $\mathrm{ADH}$.

\section{Methods}

\section{A. Assay method for $A D H$}

1) Exteriorization of the urinary bladder. Female rats of the Sprague-Dawley strain, weighing 100 to $120 \mathrm{~g}$, were anesthetized with ether. After shaving the skin about $1 \mathrm{~cm}$ above the symphysis pubis, the linea alba was incised and the peritoneum was opened. The top of the bladder was drawn out with fine forceps. The upper half of the bladder was cut off, and the edges were sutured with thin catgut $(5-0)$ to the edges of the skin

\footnotetext{
* Submitted for publication May 11, 1963; accepted April 21, 1964.

Supported by U. S. Public Health Service grant AM 06427-01 and a grant from the Sandoz Co., Hanover, N. J.

Presented at the annual meeting of the American Society for Clinical Investigation, Atlantic City, N. J., April 1963.

† From the Laboratory of Clinical Research, Hadassah University Hospital, and the Hebrew UniversityHadassah Medical School, Jerusalem, Israel; Celia Davidson Fellow in metabolic and renal diseases.
}

incision. Eight sutures were utilized, the first two being placed at the superior and inferior margins in the mid-line of the bladder. The mid-line can be identified by a fine dorsal or posterior mesentery. Care was taken not to twist the bladder during suturing. Distortion of the trigone could lead to ureteral obstruction. Four to five days after surgery the rats could be used for the assay. The same rats could be used twice at an interval of 4 to 6 days. After this period there frequently developed ascending pyelitis and pyelonephritis.

2) Assay. The rats were hydrated as well as anesthetized by giving $12 \%$ ethanol in water by stomach tube. The rats were given two doses, each equal to $3 \%$ body weight, at 30-minute intervals; a third dose, given after 20 minutes, was about $2 \%$ of the body weight. The amount of ethanol given with the third dose varied according to the state of the individual animal. Some rats were completely anesthetized by the first two doses, and in this case only tap water was administered as the third dose; others were quite awake and therefore needed an additional dose of $12 \%$ ethanol. Infrequently, in-between doses were given. Care was taken not to give larger amounts of ethanol than necessary to anesthetize the rats as this could bring on shock and even death.

When anesthesia was sufficiently deep, at the longest, 10 to 15 minutes after the third dose, a little vaseline was applied around the exteriorized bladder, and the animal was laid prone on a table-like board. A small funnel that fitted through a hole in the board was put in contact with the skin around the exteriorized bladder so that the urine flowed directly through this funnel into graduated tubes that could be read to $0.05 \mathrm{ml}$. These tubes were made from $5.0-\mathrm{ml}$ serological pipettes. By means of a constant infusion pump, $0.12 \mathrm{ml}$ per minute of a solution containing $0.3 \% \mathrm{NaCl}, 1.67 \%$ glucose, and $1.2 \%$ ethanol was infused into a tail vein, through a 25-gauge, 2-inch needle. The hub of the latter was broken off, and 1 of its length was inserted into the distal end of a 5-inch piece of polyethylene tubing (i.d., 0.023 inch; o.d., 0.038 inch). ${ }^{1}$ The proximal end was attached to an adapter into which the tubing from the constant infusion pump fit. The dead space of the needle, polyethylene tubing, and adapter was 0.05 to $0.08 \mathrm{ml}$. The glucose in the infusion solution did not cause a detectable glycosuria.

\footnotetext{
1 Intramedic polyethylene tubing, catalogue no. PE50, Clay-Adams Co., Inc., New York, N. Y.
} 
TABILE I

Percentage of reduction in urine flow after administration of different amounts of antidiuretic hormone (ADH, arginine-vasopressin)

\begin{tabular}{|c|c|c|c|c|c|c|c|c|c|}
\hline \multirow[b]{2}{*}{$\mathrm{ADH}$} & \multirow{2}{*}{$\begin{array}{l}\text { No. of } \\
\text { rats }\end{array}$} & \multicolumn{2}{|c|}{ Weight of rats } & \multicolumn{2}{|c|}{ Basal urine flow } & \multicolumn{3}{|c|}{ Per cent reduction } & \multirow{2}{*}{$\begin{array}{c}\text { SD expressed as } \\
\text { per cent of } \\
\text { the mean }\end{array}$} \\
\hline & & Range & Mean & Range & Mean & Range & Mean & $\mathrm{SD}$ & \\
\hline$\mu U / m l$ & \multicolumn{3}{|c|}{$g$} & \multicolumn{2}{|c|}{$\mathrm{ml} / 10 \mathrm{~min}$} & & & & \\
\hline 0.25 & 8 & $100-120$ & 105 & $1.0-1.3$ & 1.05 & $3.3-6.7$ & 4.4 & 1.43 & 36 \\
\hline 0.50 & 11 & $100-120$ & 107 & $1.0-1.2$ & 1.03 & $12.5-15.1$ & 14.0 & 0.98 & 7 \\
\hline 1.00 & 18 & $100-120$ & 110 & $1.0-1.35$ & 1.1 & $28.6-32.0$ & 30.0 & 0.92 & 3 \\
\hline 1.50 & 13 & $100-120$ & 105 & $1.0-1.2$ & 1.05 & $44.8-48.2$ & 47.0 & 1.35 & 3 \\
\hline 2.00 & 5 & $100-120$ & 100 & $1.0-1.4$ & 1.1 & $53.3-57.7$ & 54.7 & 2.74 & 5 \\
\hline 2.50 & 5 & $100-120$ & 104 & $1.0-1.25$ & 1.07 & $61.2-64.0$ & 62.0 & 2.74 & 4.5 \\
\hline 5.0 & 6 & $100-120$ & 106 & $0.9-1.25$ & 1.1 & $92.0-96.5$ & 93.7 & 1.50 & 0.2 \\
\hline
\end{tabular}

Urine volumes were measured every 10 minutes. In approximately $50 \%$ of the operated animals a suitable diuresis ( $>0.8 \mathrm{ml}$ per 10 minutes) could be achieved after 30 to 60 minutes of the infusion. Only these animals were used for the assay. When the urine volumes were constant for three 10-minute periods (usually between 1.0 and $1.3 \mathrm{ml}$ per 10 minutes), the test solution was injected into the tail vein in a volume of $1.0 \mathrm{ml}$ immediately after the end of the third 10-minute period.

The injection was given over a 30 -second interval into the proximal end of the polyethylene tubing attached to the needle. During this interval the tubing from the constant infusion pump was disconnected from the adapter. The material in the dead space of the needle, tubing, and adapter was delivered to the animal by the reinstituted constant infusion. The procedure of disconnecting, injecting, and reconnecting must be done in such a way that air bubbles are not injected into the rat. Any air injection will prevent a reproducible response and the establishment of a stable base line. Test solutions should be about isotonic to the blood (saline, plasma, serum, etc.), and they were at room temperature when injected. The urine volumes in the periods following were observed till the excretion returned to the control level. Then the animals were ready for injection of another test substance. Usually 2 to 3 test substances, depending on their ADH content, can be given to an animal in a single run.

Rats to be used for assaying samples with unknown $\mathrm{ADH}$ content were injected first with $1.0 \mathrm{ml}$ saline containing 0.5 to $1.0 \mu \mathrm{U}$ of synthetic arginine-vasopressin. ${ }^{2}$ The dilutions of arginine-vasopressin were made from a freshly opened 1-ml vial and used immediately. Residual undiluted standard was immediately frozen, to be diluted and used again at the end of the assay run. The frozen undiluted arginine-vasopressin was stable for at least 10 days. Longer periods of freezing were not evaluated. The potency of freshly opened samples of synthetic arginine-vasopressin was compared with a sample of the International Standard on three occasions over a

2 Synthetic arginine-vasopressin was obtained from the Sandoz Co., Hanover, N. J., through the courtesy of $\mathrm{Mr}$. Harry Althouse.
6 -week period and found to contain the labeled activity. ${ }^{3}$ In many cases a second standard dose was injected at the end of the assay run. The response to the injected standards was plotted on the dose-response curve. Throughout these studies the range of response fell within the limits noted in Table I. Unknown samples containing, before or after the initial dilution, greater amounts than 1.5 to $2.0 \mu \mathrm{U}$ per $\mathrm{ml}$, were then diluted or rediluted and injected again into another assay animal. The results agreed always within $0.5 \mu \mathrm{U}$ per $\mathrm{ml}$ when calculated for the original sample. The ADH content of the plasma was read from the dose-response curve (Figure 1), which will be described in greater detail in Results.

Three 0.9-ml samples of dog plasma containing at least $40 \mu \mathrm{U}$ per $\mathrm{ml}$ of endogenous antidiuretic activity were mixed with $0.1 \mathrm{ml}$ of $0.1 \mathrm{M}$ sodium-thioglycolate $(5,6)$, or with $0.1 \mathrm{ml}$ of normal saline as controls. After standing 1 hour at room temperature, the control samples still contained between 30 and $40 \mu \mathrm{U}$ of antidiuretic activity, whereas those containing thioglycolate had no antidiuretic activity. As none of the unknown human samples were from pathologic or unusual studies, thioglycolate inactivation of other samples was not carried out.

\section{B. Experiments on man}

These were carried out on six normal male volunteers, ranging in age from 25 to 40 . During the experiments the subjects were comfortably seated in an easy chair. After procaine infiltration, an indwelling needle was inserted into a vein of the forearm. The first blood sample was drawn about 15 minutes later. The subjects remained in the sitting position during the whole experiment, standing only to void. Blood samples were drawn at intervals of from 10 to 30 minutes into a heparinized syringe and immediately centrifuged at 3,000 rpm. Plasma was decanted and frozen by throwing in a few pebbles of dry ice (see below). Urine samples were collected at intervals of 15 to 30 minutes. Plasma samples were assayed for $\mathrm{ADH}$ activity, and osmolality was de-

3 The authors are most grateful to Dr. Wilbur Sawyer, Department of Pharmacology, Columbia University, School of Medicine, for a generous supply of International Standard. 


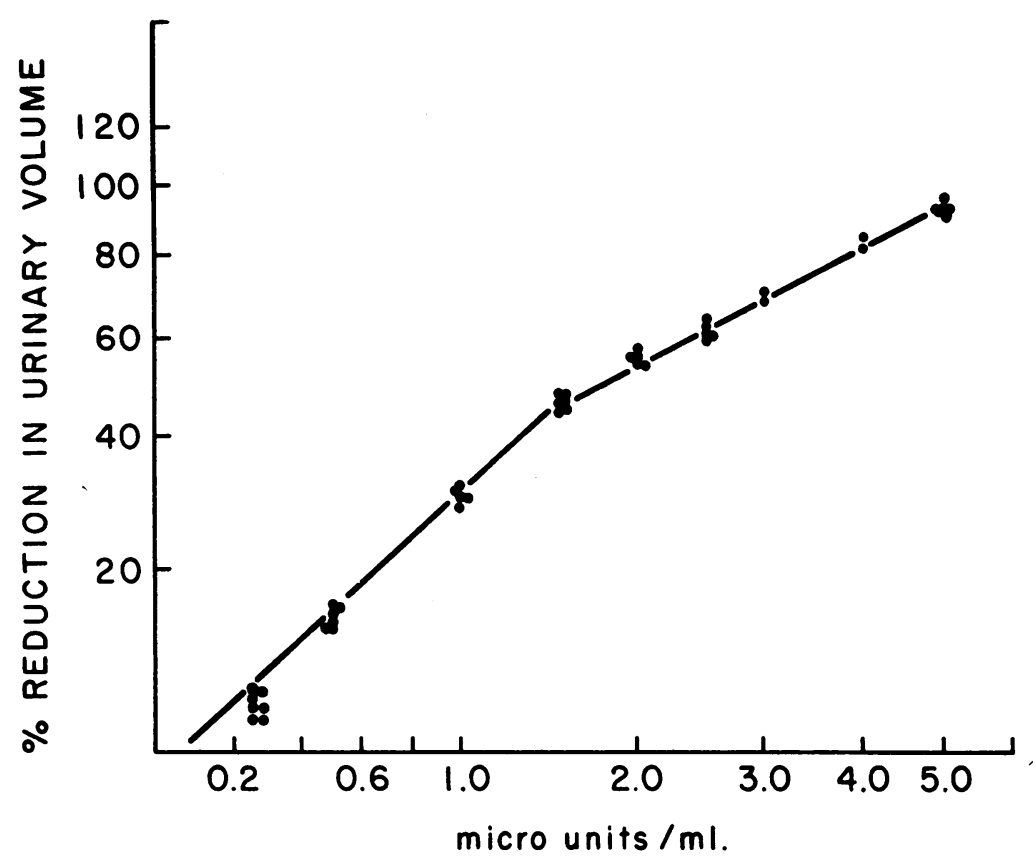

Fig 1. LOG-LOG PLOT OF THE EFFECT OF INCREASING DOSES OF ARGININEVASOPRESSIN ON THE PERCENTILE REDUCTION IN URINARY FLOW. Each point represents a different assay animal.

termined on plasma and urine samples with the Fiske osmometer.4

The general plan of the experiments called for the test subjects to arrive in the laboratory in various states of hydration. After the first blood sample was collected, an oral water load of 1,500 to $2,000 \mathrm{ml}$ was given. In some of the experiments this water load was sustained by continued oral water intake. In four subjects, after a sustained maximal water diuresis was achieved, an iv injection of 15 to $25 \mathrm{mU}$ arginine-vasopressin was given and the experiment continued until maximal water diuresis was again attained. The dose injected was calculated from the potency listed by the manufacturer on the label of the ampoule. Portions of the injected samples were not subjected to assay.

In two of the subjects participating in the latter type of experiments, two additional tests were performed. In the first, the subjects were tested after 3 days of "chronic overhydration." During these 3 days their fluid intake was 1,000 to $1,500 \mathrm{ml}$ in every 4-hour period around the clock. Urines during the whole period were hypotonic to their plasma, and the $\mathrm{ADH}$ activity of their plasma was "zero." After this period of overhydration, $15 \mathrm{mU}$ of arginine-vasopressin was again given.

In the second, the subjects were tested after a 3-day period of "chronic dehydration." During these 3 days they were allowed only $500 \mathrm{ml}$ of fluid per day. Their urines were continuously hypertonic to plasma (urinary osmolality : 1,337 to 1,348 mOsm per L). After these 3

\footnotetext{
4 Fiske Associates, Inc., Bethel, Conn.
}

days they were given a water load, and plasma and urine samples were collected and tested as before.

\section{Protein binding of endogenous $A D H$}

Forty milliliters of blood was drawn from six healthy subjects after 15 to 24 hours of water deprivation. Plasma was separated, and approximately $6 \mathrm{ml}$ was quickly placed in each Lavietes anaerobic ultrafiltration unit (7). One unit, set up in such a way that no ultrafiltration occurred, served as a control. Two sets of units (control and experimental) were kept at $4^{\circ} \mathrm{C}, 20^{\circ} \mathrm{C}$, and $37^{\circ} \mathrm{C}$. The units at $4^{\circ}$ were set up in the cold room, while those kept at $37^{\circ}$ were set up at room temperature and immediately placed in the constant-temperature oven. Approximately 10 minutes was required to set up a filtering unit and its control. The time required to obtain $2 \mathrm{ml}$ of ultrafiltrate depended on the temperature ( 2 hours at $37^{\circ} ; 4$ to 5 hours at $20^{\circ}$, and 7 to 8 hours at $4^{\circ}$ ). After $2 \mathrm{ml}$ of filtrate was obtained, the ultrafiltrates and the control plasma were assayed for $\mathrm{ADH}$ activity, with the same animal used for both samples. Two samples of plasma, obtained in a similar way as above, were dialyzed against Ringer's solution for 6 hours at $37^{\circ}$, by the technique described by Craig and King (8). $\mathrm{ADH}$ concentration on both sides of the membrane was determined.

In both ultrafiltration and dialysis, Visking membranes ${ }^{5}$ were used.

5 Supplied as dialyzing tubing by the Division of American Hospital Supply Corp., Evanston, Ill. 
TABLE II

Typical protocol of a rat assay run with saline containing known amounts of vasopressin

\begin{tabular}{rcccc}
\hline $\begin{array}{c}\text { Elapsed } \\
\text { time }\end{array}$ & $\begin{array}{c}\text { Urine } \\
\text { volume }\end{array}$ & $\begin{array}{c}\text { Dose } \\
\text { injected }\end{array}$ & $\begin{array}{c}\% \\
\text { Reduction }\end{array}$ & $\begin{array}{c}\text { Creatinine } \\
\text { excretion }\end{array}$ \\
\hline $\min$ & ml/10 min & $\begin{array}{c}\mu U / m l \text { in } \\
\text { I ml saline }\end{array}$ & & $\mathrm{mg} / 10 \mathrm{~min}$ \\
10 & 1.35 & & & \\
20 & 1.35 & & & \\
30 & 1.35 & 0.5 & & 0.065 \\
40 & 1.15 & & 14.5 & 0.065 \\
50 & 1.35 & 1.5 & & \\
60 & 1.00 & & 48.2 & 0.072 \\
70 & 1.05 & & & 0.072 \\
80 & 1.35 & 2.0 & & \\
90 & 0.80 & & 55.5 & 0.068 \\
100 & 1.15 & & & 0.066 \\
110 & 1.35 & 3.0 & 70.5 & 0.070 \\
120 & 0.85 & & & 0.072 \\
130 & 0.90 & & & 0.068 \\
140 & 1.35 & & & \\
150 & 1.35 & & & \\
\hline
\end{tabular}

\section{Results}

\section{A. Evaluation of assay method for $A D H$}

1) Sensitivity and dose-reaction curve. The minimal response, i.e., a reduction in urine flow of $0.05 \mathrm{ml}$ per 10 minutes, could be obtained consistently with $0.25 \mu \mathrm{U}$ of $\mathrm{ADH}$. Very often the same reaction could be elicited with $0.2 \mu \mathrm{U} ; 0.1$ $\mu \mathrm{U}$ gave consistently negative results, i.e., no change in urine flow could be observed. From 0.5 to $5.0 \mu \mathrm{U}$, a reproducible dose-reaction curve could be obtained (see below). The response to a given dose was measured by the absolute amount by which urine volume was lowered, expressed as a percentage of the basic urine flow. If the reduction in urine flow extended over more than one

TABLE III

Typical protocol of a rat assay run with unknown plasma samples

\begin{tabular}{|c|c|c|c|c|}
\hline $\begin{array}{c}\text { Elapsed } \\
\text { time }\end{array}$ & $\begin{array}{l}\text { Urinary } \\
\text { volume }\end{array}$ & $\begin{array}{c}\text { Material injected } \\
(1.0 \mathrm{ml})\end{array}$ & $\stackrel{\%}{\%}$ Reduction & $\begin{array}{c}\text { Creatinine } \\
\text { excretion }\end{array}$ \\
\hline $\min$ & $\mathrm{ml} / 10 \mathrm{~min}$ & \multirow{11}{*}{$\begin{array}{l}0.5 \mu \mathrm{U} \text { in saline } \\
\text { Plasma no. } 1 \\
\text { Plasma no. } 2 \\
1.0 \mu \mathrm{U} \text { in saline }\end{array}$} & & $\mathrm{mg} / 10 \mathrm{~min}$ \\
\hline 10 & 1.2 & & & 0.053 \\
\hline 20 & 1.2 & & & 0.057 \\
\hline 30 & 1.2 & & & 0.063 \\
\hline 40 & 1.05 & & 12.5 & 0.060 \\
\hline 50 & 1.2 & & & \\
\hline 60 & 0.8 & & 33.3 & 0.059 \\
\hline 70 & 1.2 & & & \\
\hline 80 & 1.00 & & 16.6 & 0.055 \\
\hline 90 & 1.2 & & & \\
\hline $\begin{array}{l}100 \\
110\end{array}$ & $\begin{array}{l}0.85 \\
1.2\end{array}$ & & 29.2 & 0.062 \\
\hline
\end{tabular}

10-minute period, the sum of the percentile reduction in each period was taken. Table I gives the results of measurements for doses of $\mathrm{ADH}$ (arginine-vasopressin), between 0.25 and $5.0 \mu \mathrm{U}$. Tables II and III give the results of a typical assay run. Creatinine excretion was measured (9) in order to demonstrate that the reduction in urine flow was not due to a lowering of glomerular filtration rate (GFR). Identical results were obtained by adding measured amounts of vasopressin in $0.1 \mathrm{ml}$ saline to $0.9 \mathrm{ml}$ plasma (rat, human, and $\operatorname{dog}$ ), which showed on previous assay no ADH activity. Table IV gives results of recovery studies on human plasma. $0.5 \mathrm{ml}$ of human plasma was mixed with $0.5 \mathrm{ml}$ of saline containing a measured amount of vasopressin, or with $0.5 \mathrm{ml}$ of another plasma with previously assayed $\mathrm{ADH}$ content. Calculated and actually assayed $\mathrm{ADH}$ were compared. Similar results were obtained in recovery studies performed with dog plasma. Figure 1 gives the dose-reaction curve plotted on logarithmic paper. As can be seen, the plot of the logarithm of the percentile reduction in urine flow against the logarithm of the dose gives one straight line for concentration from 0.5 to $1.5 \mu \mathrm{U}$ per $\mathrm{ml}$ and a second straight line with a smaller slope for concentrations from 1.5 to $5.0 \mu \mathrm{U}$ per $\mathrm{ml}$. The equations of the two lines are, respectively: $\log \%$ reduction $=1.31 \log$ dose +1.477 , and $\log \%$ reduction $=0.545 \log$ dose +1.585 . In almost all of our experiments, plasma samples were suitably diluted in order to stay in the first part of the dosereaction curve. This dilution saved time and enabled us to run more assays on one rat as the reduction in urine flow in response to this dose extends for one 10-minute period only.

2) Stability of endogenous ADH in plasma. Blood was drawn into a heparinized syringe and immediately centrifuged for 5 minutes at 3,000 rpm. Plasma was decanted and either assayed at once for its $\mathrm{ADH}$ activity or preserved by the addition of dry ice, as described below. Samples of the plasma were kept at room temperature $\left(+20^{\circ}\right)$, at $4^{\circ} \mathrm{C}$, and at $-20^{\circ} \mathrm{C}$. Table $\mathrm{V}$ shows that the plasma maintained its original activity at room temperature for 40 minutes after blood was drawn, but there was a slight but significant decrease in activity after 1 and 2 hours even on refrigeration. Plasma frozen quickly 
TABLE IV

Recovery experiments of $A D H$ in saline and plasma

\begin{tabular}{lcccc}
\hline \hline $\begin{array}{c}\text { ADH } \\
\text { in 0.5 ml } \\
\text { plasma 1 }\end{array}$ & $\begin{array}{c}\text { ADH } \\
\text { in 0.5 ml } \\
\text { plasma 2 }\end{array}$ & $\begin{array}{c}\text { ADH } \\
\text { in 0.5 ml } \\
\text { saline }\end{array}$ & $\begin{array}{c}\text { Theoretical } \\
\text { value }\end{array}$ & $\begin{array}{c}\text { Experi- } \\
\text { mental } \\
\text { value }\end{array}$ \\
\hline$\mu U$ & $\mu U$ & $\mu U$ & $\mu U / m l$ & $\mu U / m l$ \\
0 & & 2.0 & 2.0 & 2.0 \\
1.35 & & 2.5 & 3.85 & 4.0 \\
1.4 & & 0.5 & 1.9 & 2.1 \\
0.6 & 0.6 & & 1.2 & 1.1 \\
0.6 & 0.4 & & 1.0 & 0.9 \\
0.7 & 0.5 & & 1.2 & 1.4 \\
\hline
\end{tabular}

by packing with dry ice also showed a fall in activity. However, it was found that if the plasma was divided into 1 - to $2-\mathrm{ml}$ samples in $18-\times 160$ $\mathrm{mm}$ test tubes and pebbles of dry ice were dropped into it, $\mathrm{ADH}$ activity could be maintained. To avoid loss of activity during the thawing process, $\mathrm{CO}_{2}$ gas was bubbled through the samples. Each sample was thawed just before injection. As shown in Table $\mathrm{V}$, under such conditions frozen plasma can be kept at least 17 days. Once activity was lost, enriching the plasma with $\mathrm{CO}_{2}$ did not return the $\mathrm{ADH}$ activity back to the original value.

\section{B. Experiments on man}

Plasma ADH levels in various states of hydration. Table VI shows the hours of water deprivation and the plasma $\mathrm{ADH}$ levels from zero to $22.0 \mu \mathrm{U}$ per $\mathrm{ml}$. The ADH level in a normally hydrated state, i.e., where slightly hypertonic urine is excreted, seems to be between 0.5 and $2.7 \mu \mathrm{U}$ per $\mathrm{ml}$.

TABLE V

Stability of $A D H$ under various storage conditions*

\begin{tabular}{crclc}
\hline \hline Time & $+20^{\circ} \mathrm{C}$ & $+4^{\circ} \mathrm{C}$ & $-20^{\circ} \mathrm{C}$ & $\begin{array}{c}\mathrm{CO} \text { treatment, } \\
\text { kept at } \\
-20^{\circ} \mathrm{C}\end{array}$ \\
\hline $20 \mathrm{~min}$ & $100(8)$ & & & \\
$40 \mathrm{~min}$ & $100(8)$ & & & \\
$60 \mathrm{~min}$ & $75(8)$ & $85(8)$ & $95(5.5)$ & \\
$2 \mathrm{hrs}$ & $63(8)$ & $65(8)$ & $71(5.5)$ & $100(3.2)$ \\
$24 \mathrm{hrs}$ & $20(8)$ & $50(8)$ & $60(8)$ & $100(8)$ \\
7 days & & & & $100(5)$ \\
17 days & & & & $100(5)$ \\
\hline
\end{tabular}

* Values expressed as percentages of original value. Original value in microunits per milliliter given in parentheses. Stability study was carried out on six plasmas, two with original values of $8 \mu \mathrm{U}$ per ml, two with $5 \mu \mathrm{U}$ per $\mathrm{ml}$, and one each with 5.5 and $3.2 \mu \mathrm{U}$ per $\mathrm{ml}$. A given sample was assayed in one rat. Three rats were used to assay the plasmas with an original value of $8 \mu \mathrm{U}$ per $\mathrm{ml}$, two rats for the plasma samples with $5 \mu \mathrm{U}$ per $\mathrm{ml}$, and one rat each for the 5.5 and $3.2 \mu \mathrm{U}$ per $\mathrm{ml}$ samples.
Disappearance curves of endogenous and exogenous $A D H$. a) Observed results. Figures 2 and 3 represent graphically an experiment with a single water load and with sustained water-load response. Table VII gives the details of a typical experiment. In all cases basic plasma $\mathrm{ADH}$ levels fell to less than $0.25 \mu \mathrm{U}$ per $\mathrm{ml}$ in 70 to $120 \mathrm{~min}$ utes after the initial water load. In all experiments maximal water diuresis coincided with low

TABLE VI

Plasma ADH levels in various states of hydration

\begin{tabular}{|c|c|c|c|}
\hline Subject & $\begin{array}{c}\text { Hours } \\
\text { of water } \\
\text { deprivation* }\end{array}$ & $\underset{\text { content }}{\text { Plasma ADH }}$ & $\begin{array}{c}\text { Urine } \\
\text { osmolality }\end{array}$ \\
\hline & & $\mu U / m l$ & $m O s m / L$ \\
\hline C. R. K. & $0+$ & 0 & 67 \\
\hline D. A. & $0+$ & 0 & 65 \\
\hline R. B. & $0+$ & 0 & 74 \\
\hline J. W. C. & $0 \dagger$ & 0 & 128 \\
\hline J. B. & $0+$ & 0 & 76 \\
\hline G. R. & $0 \dagger$ & 0 & 60 \\
\hline J. W. C. & 1 & 0.5 & $305 \ddagger$ \\
\hline J. W. C. & 3 & 2.7 & $382^{\top}$ \\
\hline E. R. & 3 & 1.7 & 343 \\
\hline E. C. & 3 & 1.5 & 370 \\
\hline S. L. & 3 & 2.0 & 374 \\
\hline R. B. & 3 & 2.2 & 365 \\
\hline J. W. C. & 4 & 3.2 & 383 \\
\hline R. B. & 4 & 3.5 & 405 \\
\hline A. G. & 4 & 3.6 & 428 \\
\hline C. R. K. & 4 & 3.8 & 423 \\
\hline J. W. C. & 12 & 5.6 & 940 \\
\hline C. R. K. & 12 & 7.0 & 875 \\
\hline S. L. & 12 & 7.0 & 798 \\
\hline R. B. & 16 & 10.0 & 1,124 \\
\hline A. $\mathrm{G}$. & 16 & 10.5 & 956 \\
\hline G. R. & 24 & 18.0 & 1,134 \\
\hline D. A. & 24 & 18.5 & 1,124 \\
\hline D. A. & 72 & 20.0 & 1,348 \\
\hline & 72 & 22.0 & 1,337 \\
\hline
\end{tabular}

* This represents the time from the previous meal (breakfast) during which liquids (coffee, water, and milk) were taken ad libitum.

† One to two hours after 1,500 to $2,000 \mathrm{ml}$ oral water load.

$\ddagger$ This was the only random sample taken 1 hour after fluid ingestion. The urine collected at this time had been in the bladder at least 2 hours before this voiding.

or unmeasurable levels of $\mathrm{ADH}$ in the plasma. In the two individuals in whom the original water load was not sustained, plasma ADH levels started to rise again (Figure 2). Table VIII gives data on $\mathrm{ADH}$ levels before the water load and at the height of the water diuresis. Although Figures 2 and 3 demonstrate the general relationship between the water diuresis and the level of circulating $\mathrm{ADH}$, the relatively long collection periods 


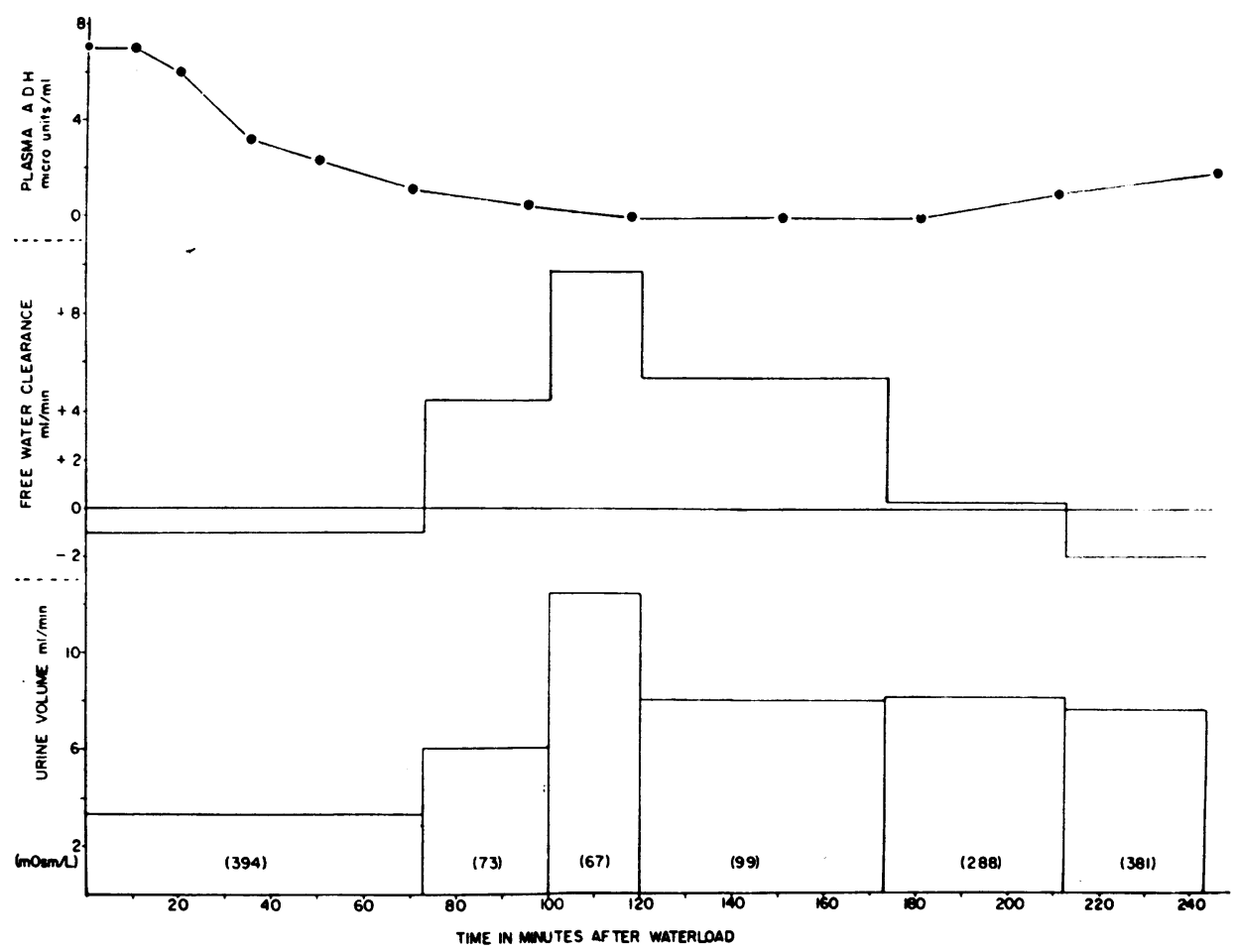

Fig. 2. Relationship Between the Fall in the concentration of ANTidiuretic hormone (ADH) IN THE PLASMA AND THE DEvELOPMENT OF A WATER DIURESis IN A NORMAL SUBJECT AFTER THE ORAL INGESTION OF 1,500 ML OF WATER.

while the rate of urinary flow is changing rapidly do not allow a critical comparison of these parameters.

b) Calculated results. Figure 4 illustrates the semilog graph for the falling $\mathrm{ADH}$ concentrations after water loading. The curves for endogenous $\mathrm{ADH}$ are composed of two parts, an initial slower and a second steeper part, both fitting fairly well the general formula of $\mathrm{C}=\mathrm{C}_{0} \cdot \mathrm{e}^{-\mathrm{KT}}$. The fractional turnover $(\mathrm{K})$ calculated from this equation for the second part of the curve seems to be identical for all individuals tested and was found to be 0.0433 per minute $\left(t_{\frac{1}{2}}, 16\right.$ minutes $){ }^{6}$

The fractional turnover of the first part of the curve apparently was related to the initial concentration of $\mathrm{ADH}$ in the plasma (Table IX). This relationship is illustrated in Figure 5. Although the slope of the first part of the curve may also

\footnotetext{
B In subject JWC the second part of the curve was represented by only two points, and in subject CRK the fit of the points is poorer than in the others, thus decreasing slightly the validity of these two curves as compared to the others.
}

have been related to the rate of change of plasma osmolality $\mathrm{d}_{\mathrm{osm}} / \mathrm{dt}$ after the intial water load, the degree of accuracy of the freezing point measurement of the plasma did not allow this relationship to be critically assessed. After the intravenous administration of vasopressin to individuals whose plasma activity was zero, the semilog plots depicted in Figure 6 were obtained. In each individual the disappearance of exogenous $\mathrm{ADH}$ was slightly slower than the disappearance of endogenous $\mathrm{ADH}$. The mean fractional turnover is 0.0327 per minute as compared with 0.0433 per minute, the $t_{\frac{1}{2}}$ being 20 to 22 and 16 minutes, respectively (Table IX).

After intravenous injection of exogenous ADH (arginine-vasopressin) during maximal water diuresis, ADH levels rose from zero to 4 to $10 \mu \mathrm{U}$ per $\mathrm{ml}$ of plasma and fell again to zero after 80 to 110 minutes.

After chronic dehydration the disappearance curves of endogenous and exogenous $\mathrm{ADH}$ were significantly steeper, whereas after chronic overhydration the curves for exogenous $\mathrm{ADH}$ were 
TABLE VII

The protocol of a typical water-load experiment begun after 24 hours of water deprivation on subject G. $R .^{*}$

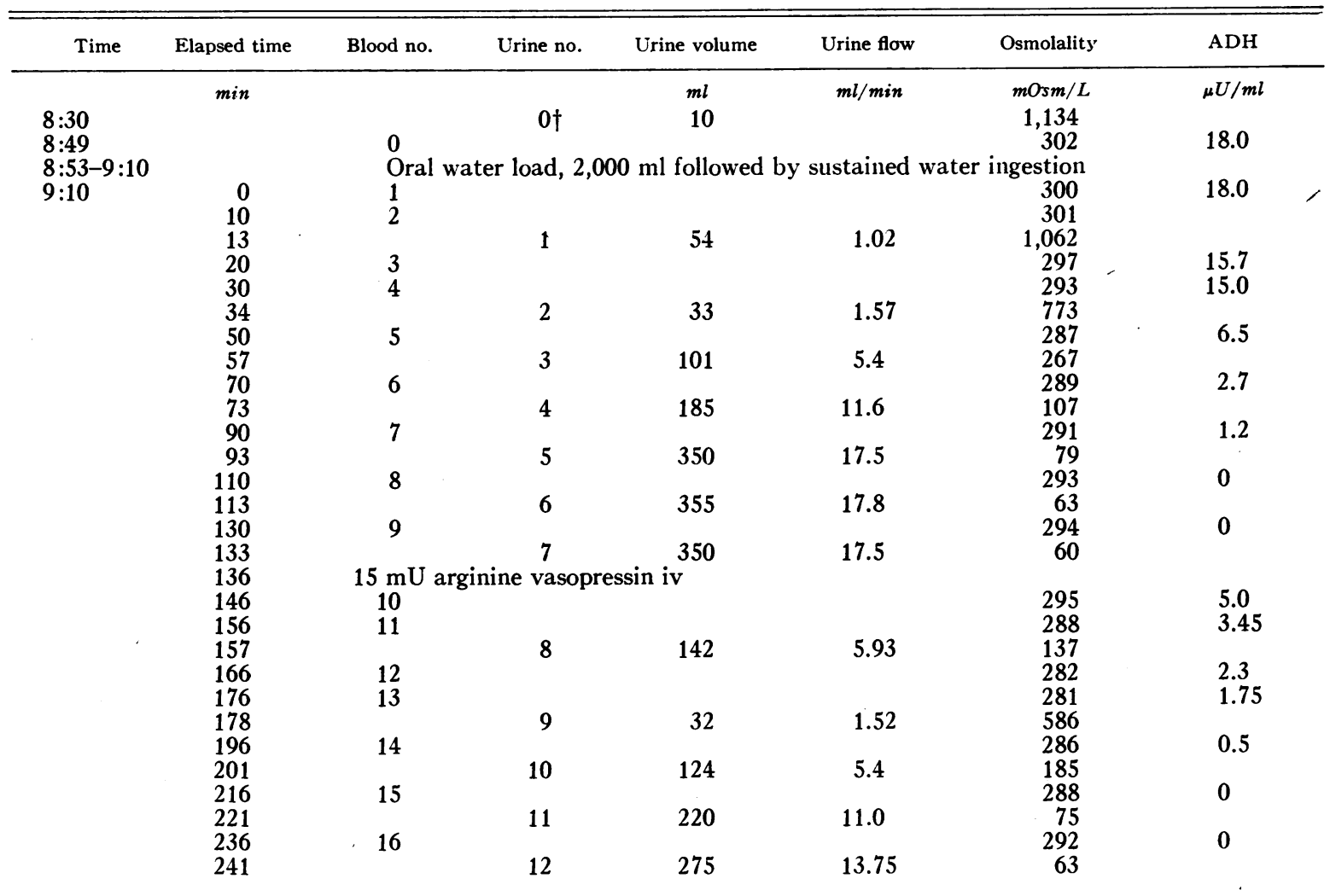

* Water deprivation means no preformed liquids ingested and high water content foods, i.e., fresh fruit and gelatin, were avoided for 24 hours.

$\dagger$ Represented a collection period of approximately 60 minutes.

less steep. (See below in calculated results, Ta- the injected amount of $\mathrm{ADH}$ and zero time conble XII, Figures 7 and 8.)

c) Volume of distribution and ADH release. After intravenous injection of vasopressin, the apparent volume of distribution was calculated by weight.

TABLE VIII

Plasma ADH levels during maximal water diuresis

\begin{tabular}{|c|c|c|c|c|c|c|c|}
\hline Subject & Weight & Height & $\begin{array}{c}\text { Duration } \\
\text { of water } \\
\text { restriction }\end{array}$ & $\begin{array}{l}\text { Basal } \\
\text { ADH }\end{array}$ & $\begin{array}{c}\text { Maximal water } \\
\text { diuresis }\end{array}$ & $\begin{array}{c}\text { Urine } \\
\text { osmolality }\end{array}$ & $\begin{array}{l}\text { ADH at mid-point } \\
\text { of maximal water } \\
\text { diuresis period }\end{array}$ \\
\hline & $\mathrm{kg}$ & $\mathrm{cm}$ & hrs & $\mu U / m \boldsymbol{l}$ & $m l / \min$ & $m O s m / L$ & \\
\hline $\begin{array}{l}\text { C. R. K. } \\
\text { J. W. C. } \\
\text { R. B. } \\
\text { J. B. } \\
\text { G. R. } \\
\text { D. A. } \\
\text { D. A. } \\
\text { J. B. }\end{array}$ & $\begin{array}{l}70.0 \\
70.4 \\
85.0 \\
72.3 \\
68.2 \\
70.9 \\
70.9 \\
72.3\end{array}$ & $\begin{array}{l}179.1 \\
190.5 \\
195.6 \\
198.1 \\
177.8 \\
247.6 \\
247.6 \\
190.5\end{array}$ & $\begin{array}{l}15 \\
12 \\
16 \\
18 \\
24 \\
24 \\
72 \\
72\end{array}$ & $\begin{array}{r}7.0 \\
5.6 \\
10.0 \\
15.0 \\
18.0 \\
18.5 \\
20.0 \\
22.0\end{array}$ & $\begin{array}{l}12.5 \\
13.0 \\
13.5 \\
11.7 \\
17.5 \\
19.7 \\
28.4 \\
12.7\end{array}$ & $\begin{array}{r}67 \\
128 \\
74 \\
76 \\
60 \\
60 \\
87 \\
97\end{array}$ & $\begin{array}{l}0.4^{*} \\
0.3^{*} \\
1.9 \dagger \\
0 \\
1.2 \dagger \\
0 \\
0 \\
0\end{array}$ \\
\hline
\end{tabular}

* Fell to undetectable amounts within the next 5 to 10 minutes.

$\dagger$ Fell to zero within the next 20 to 25 minutes. 


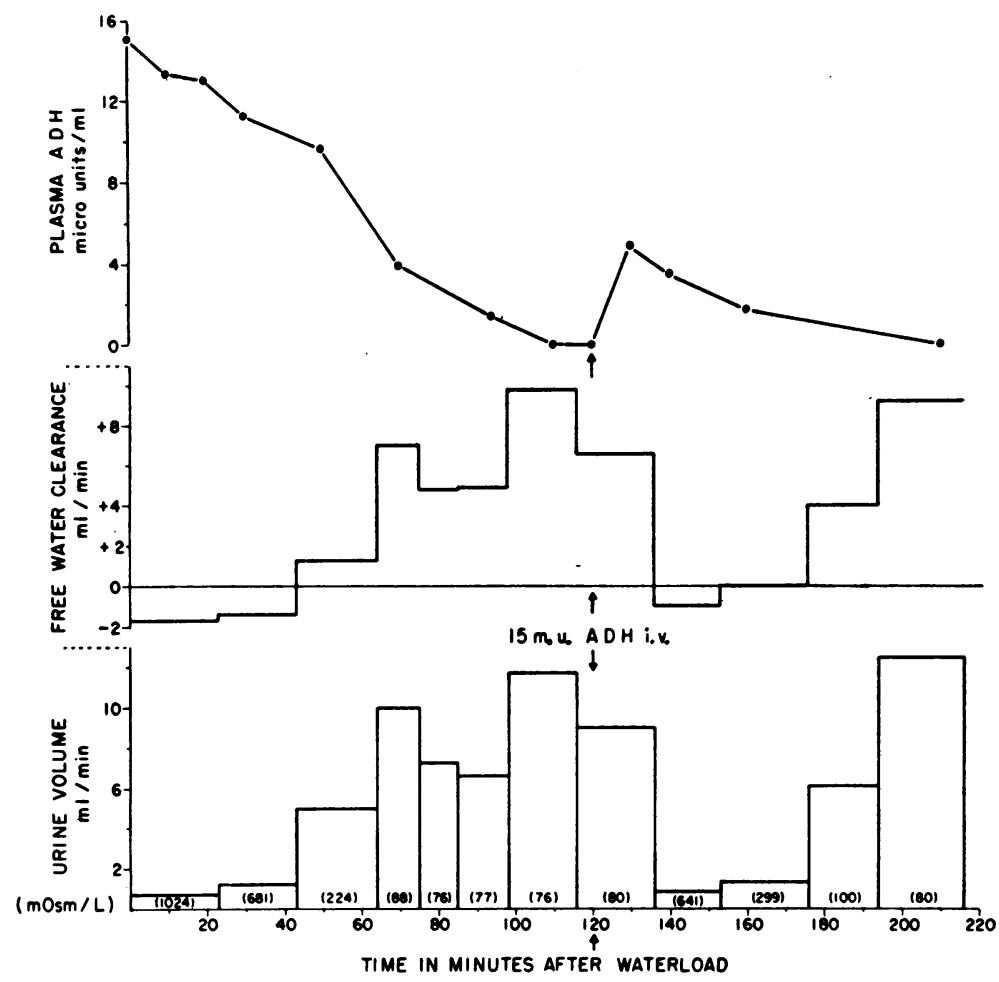

Fig. 3. EFFect of A SUStained ORAL WATER LOAd $(2,000 \mathrm{ML})$, FOllowed BY THE INTRAVENOUS INJECTION OF ARGININE-VASOPRESSIN, ON THE PLASMA LEVEL OF ADH AND THE PARAMETERS OF A MAXIMAL WATER DIURESIS.

The correlation between the slope of the first part of the disappearance curve and the initial endogenous $\mathrm{ADH}$ concentration in plasma, despite the extreme constancy of the second part of the curve, suggests that the differences between the various initial slopes may represent the quantity of $\mathrm{ADH}$ released from the posterior lobe subsequent to water ingestion (see Discussion).

If we assume that in the steady state the basal concentration of $\mathrm{ADH}$ in the plasma is relatively constant, that the input and removal rates are equal, that the volume of distribution of the hor-

TABLE IX

The half-time fractional turnover of endogenous and exogenous ADH in six normal subjects

\begin{tabular}{|c|c|c|c|c|c|c|}
\hline Subject & $\begin{array}{c}\text { Hours } \\
\text { of water } \\
\text { deprivation }\end{array}$ & Type of curve & $\begin{array}{c}\text { Basal plasma } \\
\text { ADH }\end{array}$ & Half-time & $\mathrm{K}_{1}$ in $\min ^{-1 *}$ & $\mathrm{~K}_{2}$ in $\min ^{-1} \dagger$ \\
\hline & & & $\mu U / m l$ & $\min$ & & \\
\hline I. W. C. & 12 & Endogenous & 5.6 & 16.0 & 0.014 & 0.043 \\
\hline C. R. K. & 15 & Endogenous & 7.0 & 16.0 & 0.0117 & 0.0433 \\
\hline \multirow[t]{2}{*}{ R. B. } & 18 & Endogenous & 10.0 & 16.5 & 0.0099 & 0.0420 \\
\hline & & Exogenous & $10.0 t$ & 22.0 & & 0.0314 \\
\hline \multirow[t]{2}{*}{ J. B. } & 18 & Endogenous & 15.0 & 16.0 & 0.00767 & 0.0433 \\
\hline & & Exogenous & $5.0 \S$ & 20.0 & & 0.0346 \\
\hline \multirow[t]{2}{*}{ G. R. } & 24 & Endogenous & 18 & 16.0 & 0.00693 & 0.0433 \\
\hline & & Exogenous & $5 \S$ & 20 & & 0.0346 \\
\hline \multirow[t]{2}{*}{ D. A. } & 24 & Endogenous & 18.5 & 16.0 & 0.00557 & 0.0433 \\
\hline & & Exogenous & $4.4 \S$ & 23.0 & & 0.0301 \\
\hline
\end{tabular}

$* \mathrm{~K}_{1}=$ fractional turnover of initial part of curve.

$+K_{2}=$ fractional turnover of second part of curve.

$\$ 10$ minutes after injection of $25 \mathrm{mU}$ arginine-vasopressin.

$\$ 10$ minutes after injection of $15 \mathrm{mU}$ arginine-vasopressin. 
mone is the plasma volume, and that removal is proportional to plasma concentration, then steadystate secretion rate equals the fractional turnover $\left(\mathrm{K}_{2}\right.$, Table IX) $\times$ estimated plasma volume $\times$ initial concentration. The results of these calculations are listed in Table XI.

d) The effect of chronic over-and dehydration. Figures 7 and 8 compare the disappearance curves of endogenous and exogenous $\mathrm{ADH}$ after 24 hours of water deprivation, 3 days of water restriction, and 3 days of overhydration in the same individuals. Table XII compares the relevant data. The turnover rate is significantly decreased after chronic overhydration and significantly increased after chronic dehydration. As a consequence of the latter, the calculated "steady-state"

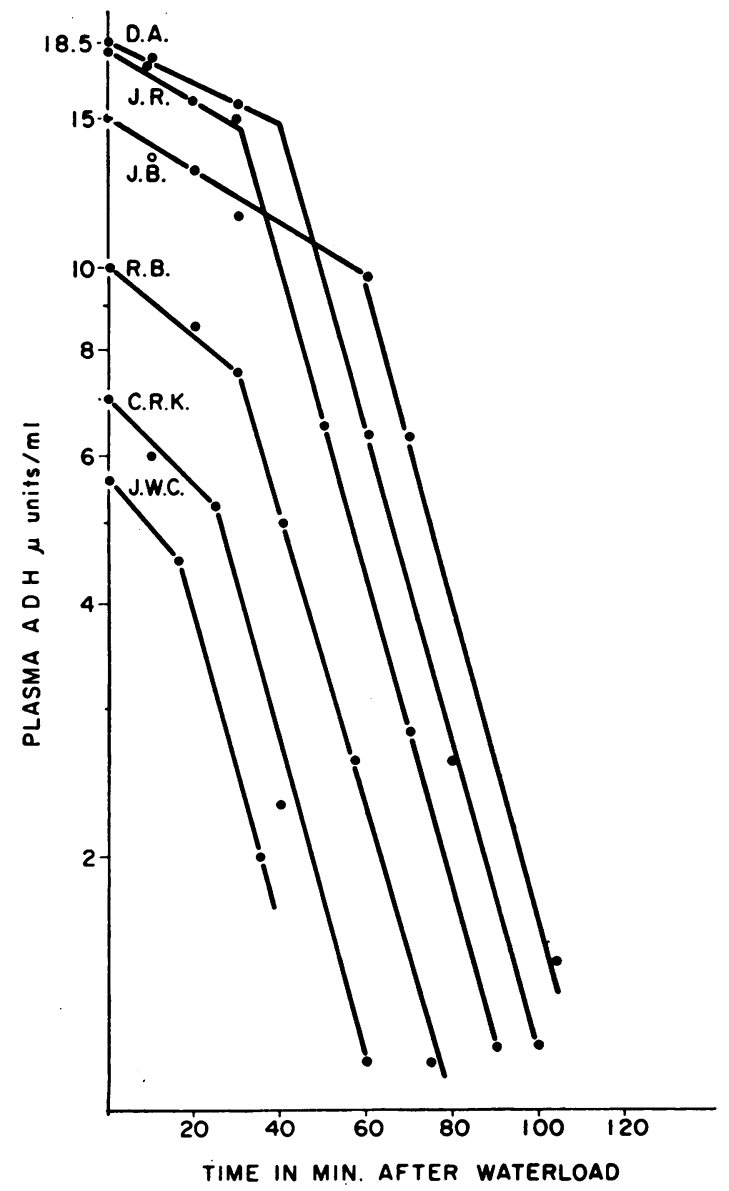

Fig. 4. Semilogarithmic disappearance of ADH FROM THE PLASMA OF NORMAL SUBJECTS, IN VARIOUS STATES OF HYDRATION, AFTER AN ACUTE ORAL WATER LOAD. Each curve represents a different subject. The straight lines represent visual approximation to the points.

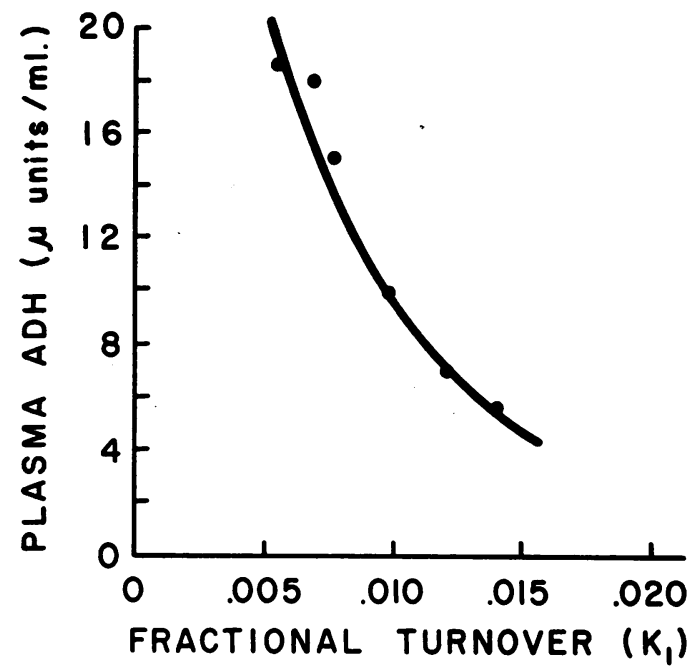

Fig. 5. Relationship, after VARying Periods OF DEHYDRATION, BETWEEN THE INITIAL LEVEL OF ADH IN THE PLASMA AND THE SLOPE OF THE FIRST PART OF THE DISAPPEARANCE CURVE. (See Figure 4.) The line represents a visual approximation to the points.

secretion rate increased more than twofold in subject J.B. and almost twofold in subject D.A. (Table XII).

\section{Ultrafiltration and dialysis}

Table XIII demonstrates that endogenous ADH seems to be completely ultrafiltrable and dialyzable. Values for $\mathrm{ADH}$ concentration in the ultrafiltrate of $4^{\circ}, 20^{\circ}$, and $37^{\circ} \mathrm{C}$, as well as the dialyzate at $37^{\circ}$, are practically identical with the control plasma.

\section{Discussion}

The present investigation not only confirmed Heller and Stulc's (3) observations but, by the slight modification of maintaining hydration by continuous intravenous infusion rather than by stomach tube, detected as little as $0.25 \mu \mathrm{U}$ of $\mathrm{ADH}$. Heller pointed out that the limitation of the method was the difficulty of obtaining a constant base line of urinary volume. In the present study we found that by switching from discontinuous oral to continuous intravenous administration, the necessary constancy of base-line urinary flow could be achieved. The disappearance of antidiuretic activity in all water-loaded subjects, the accuracy of the recoveries from the diluted plasma (Table IV), as well as inactivation by sodium- 
thioglycolate, strongly suggest that this assay specifically detected ADH. Furthermore, the authors (10) could find no antidiuretic activity in the plasma of two dehydrated patients with vasopressin-sensitive diabetes insipidus. The results suggest that physiologic studies with a more elaborate extraction procedure are unnecessary. However, to prevent partial or complete loss of activity the special precautions described in the present investigation must be observed (see Table $\mathrm{V}$ ).

The zero levels of ADH referred to in the present study represent less than $0.25 \mu \mathrm{U}$ per $\mathrm{ml}$. The justification for considering this as a physiologically meaningful term will be discussed below.

The two slopes in the dose-response curve of Figure 1 indicate the complicated nature of the response to $\mathrm{ADH}$ within this range of dosage. It obviously involves all the multiple factors

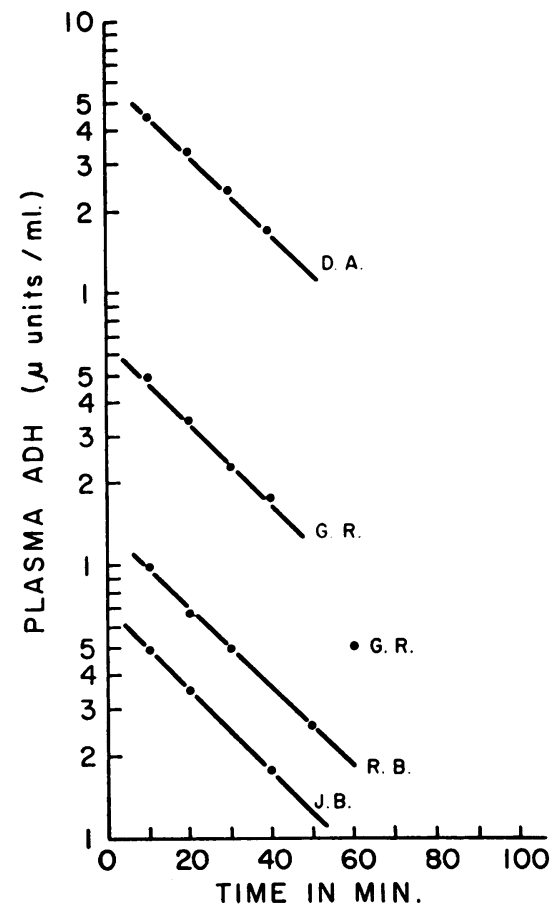

Fig. 6. Semilogarithmic Disappearance From the PLASMA OF INTRAVENOUSLY ADMINISTERED ARGININE-VASOPRESSIN IN NORMAL WATER-LOADED SUBJECTS. The straight line represents the visual approximation to the points. The line G.R. has not been drawn to incorporate the lowest point $(0.5 \mu \mathrm{U}$ per $\mathrm{ml})$ observed in this subject. The reason for this marked deviation is unclear. Unfortunately, a sample with a comparably low but detectable concentration was not obtained from the other subjects receiving arginine-vasopressin.

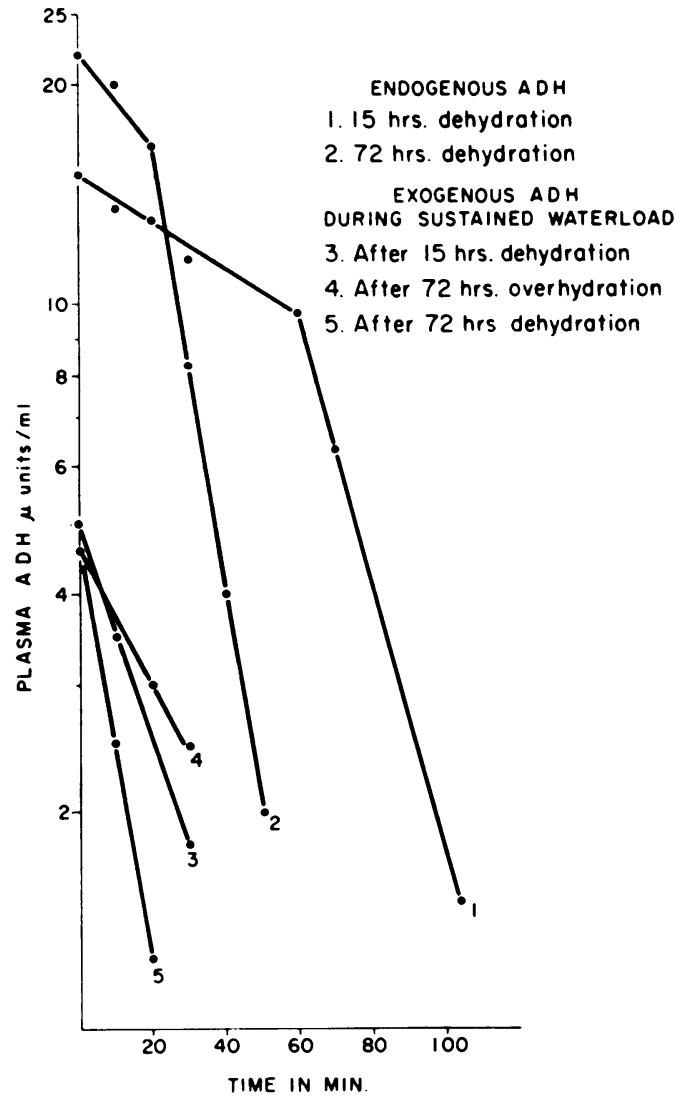

Fig. 7. EFFect of Various STAtes OF HyDRation IN SUBJECT J.B. ON THE DISAPPEARANCE FROM THE PLASMA OF ENDOGENOUS ADH AND SYNTHETIC ARGININE-VASOPRESsin (Exogenous $\mathrm{ADH}$ ). The straight line represents the visual approximation to the points.

necessary to convert the urine from that of maximal water diuresis to that of a significantly hypertonic antidiuresis.

Basal ADH level in various states of hydration (Table $V I$ ). The range of $\mathrm{ADH}$ concentrations ( 0.5 to $2.7 \mu \mathrm{U}$ per $\mathrm{ml}$ ) detected in the plasma of normally hydrated subjects (within 3 hours of previous ad lib fluid ingestion) was similar to the levels found by Heller and Stulc (4). Since completion of this work, the paper on $\mathrm{ADH}$ assay by Yoshida, Motohashi, Ibayashi, and Okinaka (11) has appeared. These authors extracted $\mathrm{ADH}$ from human plasma with trichloroacetic acid and XE-64 resin and found a mean concentration of $\mathrm{ADH}$ in the plasma of normally hydrated humans of $1.9 \pm 0.3 \mu \mathrm{U}$ per $\mathrm{ml}$. This correlates with indirect observations that the normally hydrated subject generally excretes a mod- 
TABLE $X$

Apparent volume of distribution of injected $A D H$

\begin{tabular}{cccccc}
\hline \hline Subject & $\begin{array}{c}\text { Body } \\
\text { weight }\end{array}$ & $\begin{array}{c}\text { Extrapolated } \\
\text { zero value }\end{array}$ & $\begin{array}{c}\text { Injected } \\
\text { ADH }\end{array}$ & $\begin{array}{c}\text { Volume of } \\
\text { distribution }\end{array}$ & $\begin{array}{c}\text { Volume of distribution } \\
\text { as percentage of } \\
\text { body weight }\end{array}$ \\
\hline & $k g$ & $\mu U / m l$ & $m U$ & $m l$ & \\
R. B. & 71 & 14.5 & 25 & 1,770 & 2.5 \\
J. B. & 80 & 7.1 & 15 & 2,120 & 2.6 \\
G. R. & 71 & 7.3 & 15 & 2,030 & 2.9 \\
D. A. & 99 & 5.9 & 15 & 2,550 & 2.6 \\
\hline
\end{tabular}

erately hypertonic urine, and indicates that in this state a continuous low level of $\mathrm{ADH}$ secretion is taking place. Increasing degrees of dehydration are associated with progressive increments in the basal concentration of ADH. After 24 hours of water deprivation $\mathrm{ADH}$ plasma levels reached $18.5 \mu \mathrm{U}$ per $\mathrm{ml}$, and after 3 days of chronic dehydration the levels rose to $22.0 \mu \mathrm{U}$ per ml. Our

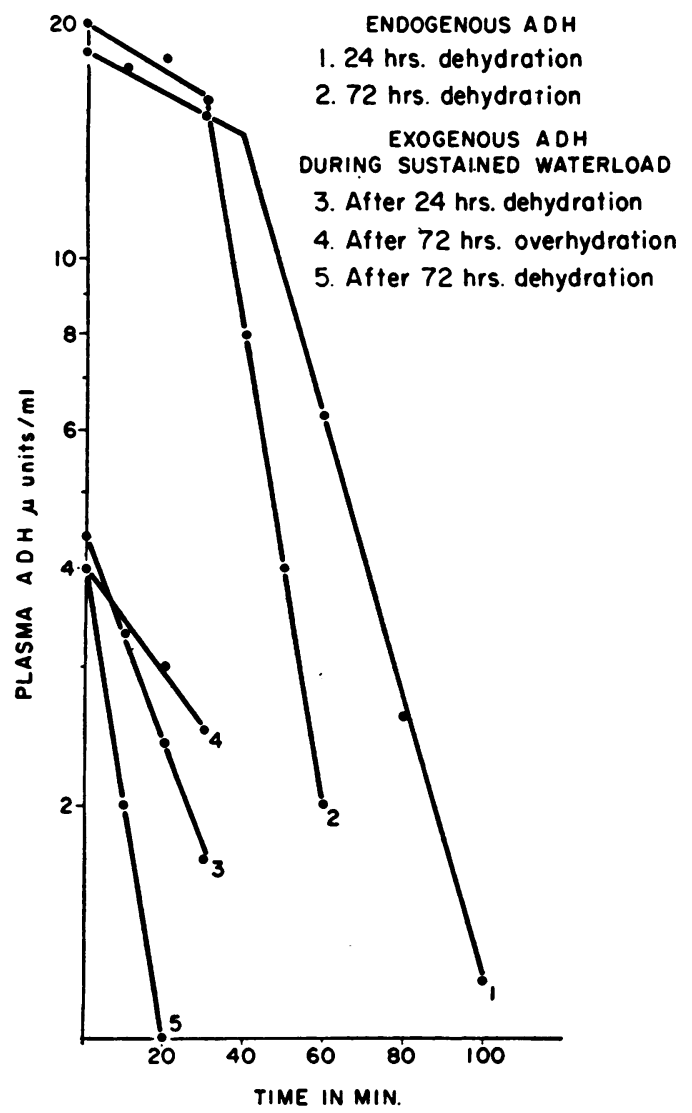

Fig. 8. EFFEcts OF VARIOUS STATES OF HYDRATION IN SUBJECT D.A. ON THE DISAPPEARANCE FROM THE PLASMA OF ENDOGENOUS ADH AND SYNTHETIC ARGININE-VASOPRESSIN (EXogenous ADH). The straight line represents the visual approximation to the points. observed values closely approximate those indirectly calculated by Lauson (12). The values observed by others utilizing a large number of different assay techniques have been completely tabulated by Lauson (12). Unfortunately, these values cannot be critically compared to those of the present study because of the different levels of sensitivity of the various assay procedures.

Turnover of circulating endogenous $A D H$ after periods of dehydration up to 24 hours. In every subject the disappearance of endogenous circulating $\mathrm{ADH}$ after administration of an acute or sustained water load was characterized by two distinct semilogarithmic curves (Figure 4). If the basal plasma levels during the first 24 hours of deprivation are a consequence of the degree of dehydration (Table VI), this suggests that the rate of release of $\mathrm{ADH}$ is a function of the degree of dehydration. The direct measurements of $\mathrm{ADH}$ activity in the hypothalamus and posterior lobe of various animals with different degrees of dehydration (13-19), suggesting both increased production and increased release of antidiuretic material, are consistent with the present observations. Although the slopes of the first part of the disappearance curve were inversely correlated with the basal ADH plasma level (Table IX, Figure 5 ), that of the second, in periods of dehydration up to 24 hours, did not demonstrate this relationship. As the second part of the curve probably indicates peripheral removal of circulating $\mathrm{ADH}$, when no further hormone was entering the bloodstream, the different slope of the first part may represent the continued, but diminishing, release of hormone from the posterior lobe. The diminishing release would be secondary to a diminishing osmotic stimulation of the neurohypophysis during absorption of the water load. Although this explanation for the continued release of the 
TABLE XI

Calculated steady-state secretion rate during moderate dehydration

\begin{tabular}{cccccc}
\hline \hline Subject & $\begin{array}{c}\text { Hours of water } \\
\text { deprivation }\end{array}$ & $\begin{array}{c}\text { Basal ADH } \\
\text { plasma level }\end{array}$ & Plasma volume* & $\mathrm{K}_{2}$ in $\min ^{-1}$ & $\begin{array}{c}\text { Steady-state } \\
\text { ADH secretion }\end{array}$ \\
\hline & & $\mu U / m l$ & $m l$ & & $\mu U / m i n$ \\
J. W. C. & 12 & 5.6 & 3,660 & 0.0430 & 887 \\
C. R. K. & 15 & 7.0 & 3,200 & 0.0433 & 969 \\
R. B. & 18 & 10.0 & 3,220 & 0.0420 & 1,394 \\
J. B. & 18 & 15.0 & 3,600 & 0.0433 & 2,338 \\
G. R. & 24 & 18.0 & 3,200 & 0.0433 & 2,494 \\
D. A. & 24 & 18.5 & 4,450 & 0.0433 & 3,564 \\
\hline
\end{tabular}

${ }^{*}$ Estimated as $4.5 \%$ of body weight.

hormone is probably correct, we have recently noted that the rapid iv administration of $2.5 \%$ glucose solution, rather than oral ingestion of the water load, did not change the form of the disappearance curve in one subject (10). Examination of the second part of the disappearance curve of endogenous ADH discloses a remarkable similarity of turnover rates in all normal subjects tested, the $t_{1}$ being 16 to 17 minutes. These observed values confirm the $t_{\frac{1}{2}}$ calculated by Lauson (12) from the data of Hollander, Williams, Fordham, and Welt (20) and Lauson (21). From the latter, a $t_{1}$ of 12 to 19 minutes, and from the former, 10 to 12 minutes was calculated.

In the normal subjects of the present study zero levels were attained 70 to 120 minutes after the initial water load. Although the assay could not differentiate between a true zero and $0.2 \mu \mathrm{U}$ per $\mathrm{ml}$ of $\mathrm{ADH}$, each observed point so closely fell on a straight line that we can reasonably assume that the ADH levels truly approached zero.

Within the limits of urinary collections, peak water diuresis was obtained when the plasma concentration of $\mathrm{ADH}$ was either zero or slightly

TABLE XII

The half-time fractional turnover rate of endogenous and exogenous $A D H$, the steady-state secretion as well as maximal urine osmolality after injection of $15 \mathrm{mU}$ arginine-vasopressin

\begin{tabular}{|c|c|c|c|c|c|c|c|c|c|}
\hline Subject & $\begin{array}{c}\text { State of } \\
\text { hydration }\end{array}$ & $\begin{array}{l}\text { Typle of } \\
\text { curve }\end{array}$ & $\begin{array}{c}\text { Basal } \\
\text { plasma } \\
\text { ADH }\end{array}$ & $\begin{array}{l}\text { Minimal } \\
\text { urine } \\
\text { flow }\end{array}$ & $\begin{array}{c}\text { Maximal } \\
\text { urine } \\
\text { osmolality }\end{array}$ & $\begin{array}{c}\text { Plasma } \\
\text { osmolality }\end{array}$ & $\mathrm{K}_{2} / \min$ & $\begin{array}{l}\text { Steady-state } \\
\text { secretion } \\
\text { rate }\end{array}$ & $\underset{\text { time }}{\text { Half }}$ \\
\hline \multirow{6}{*}{ J. B. } & \multirow{3}{*}{$\begin{array}{l}\text { 18-hr water } \\
\text { deprivation } \\
\text { 72-hr dehy- } \\
\text { dration }\end{array}$} & & $\mu U / m l$ & $m l / m i n$ & $m O s m / L$ & $m O s m / L$ & & $\mu U / \min$ & $\min$ \\
\hline & & Endogenous & 15.0 & 0.4 & 1,126 & 300 & 0.0433 & 2,338 & 16 \\
\hline & & Endogenous & 22.0 & 0.8 & 1,337 & 336 & 0.0693 & 5,488 & 10 \\
\hline & 18-hr water & Exogenous* $\dagger$ & 5.0 & 0.8 & 641 & 282 & 0.0346 & & 20 \\
\hline & $\begin{array}{l}\text { deprivation } \\
\text { 72-hr dehy- }\end{array}$ & Exogenous $* \dagger$ & 5.0 & 1.2 & 812 & 293 & 0.0693 & & 10 \\
\hline & $\begin{array}{l}\text { 72-hr over- } \\
\text { hydration }\end{array}$ & Exogenous $\dagger$ & 4.6 & 2.5 & 487 & 275 & 0.0173 & & 40 \\
\hline \multirow[t]{5}{*}{ D. A. } & \multirow{2}{*}{$\begin{array}{l}\text { 24-hr water } \\
\text { deprivation } \\
\text { 72-hr dehy- } \\
\text { dration }\end{array}$} & Endogenous & 18.5 & $?<0.2$ & 1,124 & 310 & 0.0433 & 3,564 & 16 \\
\hline & & Endogenous & 20 & 0.25 & 1,348 & 332 & 0.0693 & 6,167 & 10 \\
\hline & \multirow{3}{*}{$\begin{array}{l}\text { 24-hr water } \\
\text { deprivation } \\
\text { 72-hr dehy- } \\
\text { dration } \\
\text { 72-hr over- } \\
\text { hydration }\end{array}$} & Exogenous*, $\dagger$ & 4.4 & 1.9 & 560 & 290 & 0.0315 & & 22 \\
\hline & & Exogenous*, $\dagger$ & 4.0 & 2.8 & 790 & 293 & 0.0693 & & 10 \\
\hline & & Exogenous $\dagger$ & 4.0 & 4.7 & 327 & 282 & 0.0157 & & 44 \\
\hline
\end{tabular}

* After water load.

$\dagger 10$ minutes after iv injection of $15 \mathrm{mU}$ arginine-vasopressin. 
greater (Table VIII). This suggests that ADH activity at the renal tubular site reaches zero simultaneously with or slightly before the zero level in the plasma. Therefore one may conclude that peak water diuresis in humans represents the point where blood and tissue levels of $\mathrm{ADH}$ are minimal. These observations suggest a weak or loose "binding" of the hormone at its site of action on the nephron. This is in excellent accord with the in vitro observation on the toad bladder that vasopressin can be immediately removed from the tissue by simple washing with physiological solutions.

Exogenous disappearance curves and apparent volume of distribution. Figure 6 illustrates the disappearance curves of exogenous arginine-vasopressin after rapid ( 2 to 3 seconds) intravenous administration to normal subjects during a sustained maximal water diuresis. It is apparent that the slope of the disappearance curve is slightly less steep than the curve for the disappearance of endogenous $\mathrm{ADH}$ in the same subject in the same experiment, the mean fractional turnover being 0.0342 per minute and 0.0433 per minute, respectively, and the $t_{\frac{1}{2}}, 20$ and $16 \mathrm{~min}$ utes, respectively. Schröder and Rott (22) followed the disappearance of antidiuretic activity from the plasma of three normal adults subsequent to the iv injection of $4 \mathrm{U}$ of Pitressin. ${ }^{7}$ After 10 minutes the semilogarithmic disappearance curve was a straight line between approximately $200 \mu \mathrm{U}$ per $\mathrm{ml}$ and $40 \mu \mathrm{U}$ per $\mathrm{ml}$ with a $\mathrm{t}_{\frac{1}{1}}$ of 7 to $8 \mathrm{~min}$ utes. It is difficult to assess Schröder and Rott's (22) results properly. First, the $4 \mathrm{U}$ of Pitressin given intravenously was an extremely large dose physiologically. The patients developed headaches and abdominal cramps, and acute arterial vasoconstriction probably occurred also. What effect these physiologic changes would have on the disposal of the hormone is unknown. Secondly, in Figure 3 of their paper they have plotted the disappearance of ADH after the Pitressin injection from $100 \mu \mathrm{U}$ per $0.5 \mathrm{ml}$ down to $1 \mu \mathrm{U}$ per $0.5 \mathrm{ml}$ of plasma; yet, the minimal amount of antidiuretic activity that they could accurately detect was 20 $\mu \mathrm{U}$. Their assay used the ethanol-anesthetized rat. We have assumed from the text of their paper that there was a 10 -fold error in labeling the ordinate in Figure 3.

7 Parke, Davis \& Co., Detroit, Mich.
TABLE XIII

Concentration of endogenous $A D H$ in anaerobic ultrafiltrate and dialyzate compared with control plasma

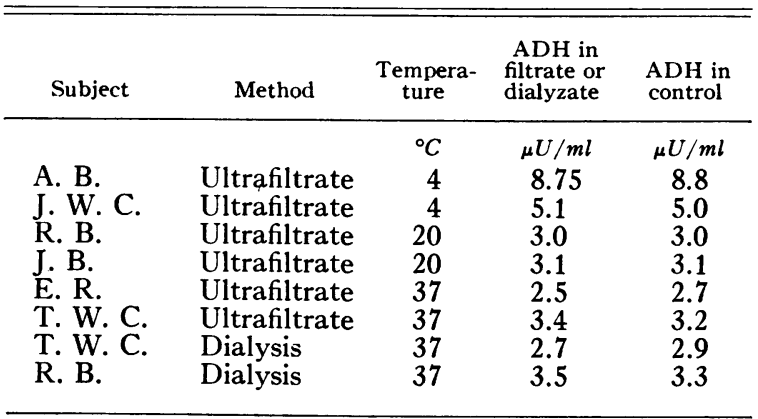

When the disappearance curve for exogenous $\mathrm{ADH}$ is extrapolated to zero time through the 10 minute point, and the zero time value divided into the injected dose, an apparent volume of distribution is obtained (Table $\mathrm{X}$ ). This volume ranged between 2 and $3 \%$ of the body weight, a value less than the generally accepted figure for plasma volume of 4 to $5 \%$ of body weight (23).

In recent experiments the authors (10) have observed that the volume of distribution of exogenous $\mathrm{ADH}$ in hydrated dogs and rats approximates the true plasma volume when calculated from the "steady-state" concentrations of $\mathrm{ADH}$ in the plasma collected during a continuous infusion of the hormone and the fractional turnover rate $(\mathrm{K})$, estimated from the plasma disappearance curve after the infusion was stopped. It is difficult to explain why the volume of distribution (2 to $3 \%$ body weight) calculated from the extrapolated zero time concentration of $\mathrm{ADH}$ and the injected dose should be less than the true volume. The validity of this technique is based on the assumption that an insignificant amount of the injected $\mathrm{ADH}$ has left the volume of distribution during the mixing phase. However, the rapid disappearance of the hormone, as indicated by the steepness of the slope, may indicate that a significant amount did leave the space before mixing. This would be equivalent to injecting less than the intended dose and then using the intended dose in the calculation of the volume, an error that should have overestimated the true volume of distribution. The figure of 2 to $3 \%$ of the body weight could be due to injecting more hormone than was intended or overestimating the concentration of $\mathrm{ADH}$ in the plasma at each point on the 
disappearance curve. Although both of these possibilities are very unlikely, the authors do not believe that in the present study the extrapolation technique correctly estimates the true volume of distribution. If a figure of 4 to $5 \%$ of the body weight is correct, then as others have suggested (12) $\mathrm{ADH}$ distributes in a volume equivalent to plasma volume. Most authors $(24,25)$ explained this distribution by assuming binding of the active peptide to plasma proteins. We, however, utilizing both anaerobic ultrafiltration and dialysis, could not demonstrate any appreciable binding to plasma proteins in vitro (Table XIII). Similar results were obtained by Bocanegra and Lauson (26) and Lauson (27) in the dog, but Thorn and Silver (25) concluded that the hormone was bound in significant quantities to plasma proteins in the rat. Although this suggests a species difference, the present authors found the antidiuretic activity in rat plasma to be completely ultrafilterable and dialyzable (10).

If these observations indicate that there is no $\mathrm{ADH}$ binding to plasma proteins in vivo and that the volume distribution is equivalent to plasma volume, then the capillary membrane must represent a significant barrier to the free diffusion of $\mathrm{ADH}$. These conclusions, plus the observation that the effect at the renal tubular level (effector site) disappears practically simultaneously with the loss of the hormone from the circulation, must mean that the interstitial concentration is at all times very low relative to the plasma level and that little or no barrier exists between the interstitial compartment and the effector site.

Relationship of the previous state of hydration to the turnover rate of $A D H$. As noted earlier, the $t_{\frac{1}{2}}$ for disappearance of exogenous ADH administered during a sustained water load was 20 to 22 minutes as compared with 16 minutes for endogenous $\mathrm{ADH}$ in the same experiment (Table $\mathrm{XII})$. This indicated that either the turnover rate of synthetic arginine-vasopressin was less rapid than that of the individual's own $\mathrm{ADH}$ or that the absence of circulating $\mathrm{ADH}$ created by the sustained water load decreased the disappearance rate. If the latter were correct, the turnover of ADH should be influenced by chronic dehydration or overhydration, respectively, the former increasing, the latter decreasing the rate. The results tabulated in Table XII indicate that the state of previous hydration did indeed influence the rate of disposal of the hormone in the manner predicted. Half-life of endogenous ADH of 16 minutes was decreased to 10 minutes after chronic dehydration, and the half-life of exogenous $\mathrm{ADH}$ was increased from 20 to 22 minutes to 40 to 44 minutes after chronic overhydration.

The antidiuretic effect of $\mathrm{ADH}$ can be correlated with the previous state of hydration, overhydration inhibiting, and dehydration enhancing its action (28). This was confirmed in the present study by comparing the maximal urinary osmolality after injection of $15 \mathrm{mU}$ vasopressin into the same subject in different states of previous hydration (Table XII).

The above observations indicate that either chronic dehydration or an increase of ADH concentration in plasma both increase the turnover rate and the kidney's concentrating ability. Conversely, chronic overhydration or the absence of circulating $\mathrm{ADH}$ decreases both these phenomena. This suggests that the receptor sites for $\mathrm{ADH}$ are influenced by the state of previous hydration whether these sites are involved in a specific physiologic action or only in inactivation of the hormone. Sawyer, Chan, and Van Dyke (29) have recently demonstrated that lysine-vasopressin is less antidiuretic and less rapidly removed from the circulation of the rat than arginine-vasopressin.

Secretion rates of endogenous $A D H$ in different states of hydration. Table XI lists the steadystate secretion rates after moderate dehydration as well as the observed data from which these were calculated. In the normal state of hydration (basal ADH level of $2 \mu \mathrm{U}$ per $\mathrm{ml}$ ) the calculated rate of $\mathrm{ADH}$ secretion in these subjects (Table $\mathrm{XI}$ ) is approximately 275 to $380 \mu \mathrm{U}$ per minute. This is, as previously mentioned, associated with the excretion of a slightly hypertonic urine. Under the stimulus of dehydration this secretion rate rises to 5,488 and $6,167 \mu \mathrm{U}$ per minute after 3 days of water restriction (Table XII). The basal level of circulating $\mathrm{ADH}$ is only 10 to $20 \%$ higher at 3 days than after 18 to 24 hours of water deprivation. Therefore, the main factor contributing to the calculated increased secretion rate is the accelerated rate of turnover. The plasma osmolality after 3 days of dehydration was significantly higher than that after 18 and 24 hours (336 and 332 mOsm per I as compared with 300 
and $310 \mathrm{mOsm}$ per L, Table XII) and probably reflected the main stimulus for the increased secretion rate observed. Urinary osmolality, however, was only moderately higher (1,337 and 1,348 mOsm per $\mathrm{L}$ as compared with 1,126 and 1,124 mOsm per L, Table XII) after 3 days. The calculated secretion rate after 18 and 24 hours of dehydration probably represents the rate necessary to maintain a nearly maximally concentrated urine at physiological rates of solute excretion. Lauson (12) calculated, for a blood level of $1 \mu \mathrm{U}$ per ml, a secretion rate of $87 \mu \mathrm{U}$ per minute of $\mathrm{ADH}$ per $\mathrm{m}^{2}$. With the fractional turnover of the present study and a plasma level of $1 \mu \mathrm{U}$ per ml, a secretion rate of $140 \mu \mathrm{U}$ per minute could be calculated.

The modification of Heller and Stulc's (3) reliable bioassay for $\mathrm{ADH}$, used in the present study, has made it possible to investigate the normal physiology of ADH. With this technique it will now be possible to evaluate pathological states critically.

\section{Summary}

A sensitive and reproducible bioassay for antidiuretic hormone $(\mathrm{ADH})$ in mammalian plasna has been developed utilizing the hydrated ethanolanesthetized rat. Bladder exteriorization (3) and a continuous intravenous infusion of hypotonic solution made it possible to maintain constant water diuresis. With this preparation as little as $0.25 \mu \mathrm{U}$ of $\mathrm{ADH}$ per $\mathrm{ml}$ could be detected. At this plasma level a maximal water diuresis was always observed.

ADH disappeared from the circulation of water-loaded normal humans in an exponential manner with a $t_{\frac{1}{2}}$ of 16 to 17 minutes. The latter was increased by chronic overhydration and decreased by chronic dehydration. Calculation of the apparent volume of distribution of exogenous $\mathrm{ADH}$ from the extrapolated zero time concentration in the plasma gave a value of approximately $2.5 \%$ of the body weight. We felt that this technique underestimated the true volume of distribution and that the latter more closely approximated the plasma volume. Despite this, no binding of $\mathrm{ADH}$ to plasma proteins could be demonstrated. The peak of maximal water diuresis coincided with, or may even have preceded, the attainment of zero $(<0.25 \mu \mathrm{U}$ per $\mathrm{ml}) \mathrm{ADH}$ levels in the plasma.

\section{Acknowledgments}

We gratefully acknowledge the contribution of Dr. Shun Ling, the technical assistance of Dr. Edith Czaczkes and Miss E. Radler, and the secretarial assistance of Mrs. M. Kauder.

\section{References}

1. Jeffers, W. A., M. M. Livezey, and J. H. Austin. A method for demonstrating antidiuretic action of minute amounts of Pitressin; statistical analysis of results. Proc. Soc. exp. Biol. (N. Y.) 1942, 50, 184.

2. Dicker, S. E. A method for assay of very small amounts of antidiuretic activity with a note on the antidiuretic titre of rats' blood. J. Physiol. (Lond.) 1953, 122, 149.

3. Heller, J., and J. Stulc. A modified method of titration of antidiuretic hormone. Čs. Fysiol. 1958, 7, 466.

4. Heller, J., and J. Stulc. Significance of a new method of titration of antidiuretic hormone. Čs. Fysiol. 1959, 8, 194.

5. Martin, P. J., and H. O. Schild. Effects of thiols on oxytocin and vasopressin receptors. Nature (Lond.) 1962, 196, 382.

6. Van Dyke, H. B., B. F. Chow, R. O. Greep, and A. Rothen. The isolation of a protein from the pars neuralis of the ox pituitary with constant oxytocic, pressor and diuresis-inhibiting activities. J. Pharmacol exp. Ther. 1942, 74, 190.

7. Lavietes, P. H. Anaerobic ultrafiltration. J. biol. Chem. 1937, 120, 267.

8. Craig, L. C., and T. P. King. Dialysis in Methods of Biochemical Analysis, D. Glick, Ed. New York, Interscience, 1962, vol. 10, p. 178 and Figure 1 .

9. Folin, O. On the determination of creatinine and creatine in the urine. J. biol. Chem. 1914, 17, 469.

10. Czaczkes, J. W., and C. R. Kleeman. The effect of various states of hydration and the plasma concentration on the turnover of antidiuretic hormone in mammals. J. clin. Invest. 1964, 43, 1649.

11. Yoshida, S., K. Motohashi, H. Ibayashi, and S. Okinaka. Method for the assay of antidiuretic hormone in plasma with a note on the antidiuretic titer of human plasma. J. Lab. clin. Med. 1963, $62,279$.

12. Lauson, H. D. Vasopressin and Oxytocin in the Plasma of Man and Other Mammals in Hormones in Human Plasma, 1st ed, H. N. Antoniades, Ed. London, J. \& A. Churchill, 1960, p. 274.

13. Howe, A., and P. A. Jewell. Effects of water deprivation upon the neurosecretory material of the desert rat (Meriones meriones) compared with the laboratory rat. J. Endocr. 1959, 18, 118.

14. Andersson, B., and P. A. Jewell. The effect of long periods of continuous hydration in the neurosecretory material in the hypothalamus of the dog. $\mathrm{J}$. Endocr. 1957, 15, 332. 
15. Bargmann, W. The neurosecretory system of the diencephalon. Endeavour 1960, 19, 125.

16. Gershenfeld, H. M., J. H. Tremezzani, and E. De Robertis. Ultrastructure and function in neurohypophysis of the toad. Endocrinology 1960, 66, 741.

17. Bargmann, W. Relationship between Neurohypophysial Structure and Function in the Neurohypophysis, H. Heller, Ed. New York, Academic Press, 1957, pp. 11-12.

18. Hild, W., R. Guillemin, and C. A. Carton. Neurosecretion in the central nervous system in Hypothalamic Hypophyseal Interrelationships, W. S. Fields, Ed. Springfield, Ill., Charles C Thomas, 1956, pp. 17-26.

19. Sawyer, W. H. Neurohypophysial hormones. Pharmacol. Rev. 1961, 13, 225.

20. Hollander, W., Jr., T. F. Williams, C. C. Fordham III, and L. G. Welt. A study of the quantitative relationship between antidiuretic hormone (vasopressin) and the renal tubular reabsorption of water. J. clin. Invest. 1957, 36, 1059.

21. Lauson, H. D. Problem of estimating the rate of secretion of antidiuretic hormone in man. Amer. J. Med. 1951, 11, 135.

22. Schröder, R., and D. Rott. Über die bestimmung und das verhalten von $\mathrm{ADH}$ im menschlichen plasma. Klin. Wschr. 1959, 37, 1175.
23. Edelman, I. S., and J. Liebman. Anatomy of body water and electrolytes. Amer. J. Med. 1959, 27, 256.

24. Heller, $H$. The state and concentration of the neurohypophysial hormones in the blood. Unpublished data cited by $\mathrm{H}$. Heller in Ciba Foundation Colloquia on Endocrinology, G. E. W. Wolstenholme and E. C. P. Millar, Eds. Boston, Little, Brown, 1957, vol. 11, pp. 3-18.

25. Thorn, N. A., and L. Silver. Chemical form of circulating antidiuretic hormone in rats. J. exp. Med. 1957, 105, 575.

26. Bocanegra, M., and H. D. Lauson. Ultrafiltrability of endogenous antidiuretic hormone from plasma of dogs. Amer. J. Physiol. 1961, 200, 486.

27. Lauson, H. D. Vasopressin and oxytocin in the plasma of man and other mammals in Hormones in Human Plasma, H. N. Antoniades, Ed. London, J. \& A. Churchill, 1960, p. 242.

28. Epstein, F. H., C. R. Kleeman, and A. Hendrikx. The influence of bodily hydration on the renal concentrating process. J. clin. Invest. 1957, 36, 629.

29. Sawyer, W. H., W. Y. Chan, and H. B. Van Dyke. Antidiuretic responses to neurohypophysial hormones and some of their synthetic analogues in dogs and rats. Endocrinology 1962, 71, 536. 